\title{
Salg af kroppen \\ - sportskvinder, massemedier og sportens kommodificering
}

Af Gertrud Pfister

Sportsfolk som nogenmodeller og sexobjekter - er sexappeal vigtigere end de sportslige prestationer? I denne artikel analyseres sammenbangen mellem sportens globalisering, kommodificeringen af sportens udovere og mediernes konkurrence.

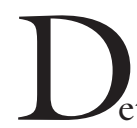

et var Anna Kournikova, som rettede min opmærksomhed mod en ny trend inden for sport. I dag kender alle Anna Kournikova, men for fire år siden vidste jeg kun, at hun var tennisspiller, og jeg blev meget overrasket, da hendes navn dukkede op i en feministisk diskussionsgruppe på internettet. Hun var anledning til en ophedet debat om sex appeal/markedsføring på sex appeal, fordi hun poserede halvnøgen på forsiden af Sports Illustrated. "We'd all rather see Lindsey Davenport on the cover smashing a ball than Kournikova batting her eyelashes in her boudoir", kommenterede Naomi Graychase, og mange andre kvinder kom med lignende udtalelser den 16. juni 2000.1

Anna Kournikova afspejler en ny udvikling inden for sport, et nyt niveau af kommodificering og seksualisering af de kvindelige sportsudøvere. Den energi og intensitet, med hvilken kvindelige såvel som mandlige sportsudøvere sælger sig selv, er også noget nyt. I dag er det ikke kun de 
sportslige resultater, der tæller - også udøverens fremtoning og image spiller en vigtig rolle i massemedierne og i offentligheden. Jeg vil demonstrere denne nye trend ved at bruge Anna Kournikova som eksempel. Det er dog ikke min intension at skrive hendes biografi eller dekonstruere hendes image og opførsel.

Jeg vil diskutere de forbindelser, der er mellem udviklingen inden for sporten, mediernes præsentation af sport og den rolle, de kvindelige sportsudøvere spiller, dels i sporten og dels i sportsdækningen.

Jeg vil søge at besvare følgende spørgsmål:

- Hvordan og hvorfor har sportsudøvernes fremtoning og opførsel ændret sig?

- Hvorfor signalerer udøverne seksualitet og fremstiller sig selv som sexobjekter? - Hvorfor fokuserer massemedierne på udøvernes erotiske udstråling?

- Hvilken rolle spiller sportsforbundene i denne udvikling?

\section{KØN SOM SOCIAL KONSTRUKTION - TEORETISKE OVERVEJELSER}

Massemediernes budskaber vil altid være påvirket og formet af de kønsstrukturer og de kønsidealer, der gør sig gældende i samfundet, noget der også gxlder måden, hvorpå sportsudøvere fremstilles. Køn i sport og i sportsreportager kan beskrives med udgangspunkt i bl.a. Judith Lorber (1994) og Robert Connells (2001) opfattelse af køn som en social konstruktion. Ifølge Lorber kan 'gender', det sociale køn, defineres som en social konstruktion, som et socialt stratifikationssystem og som en institution, der strukturerer hvert eneste aspekt af vores liv, fordi den er så indlejret i såvel familie, arbejdsliv og stat som i seksualitet, sprog og kultur. ${ }^{2}$ Det sociale køns orden er baseret på den kønsmæssige opdeling af arbejdet og legitimeret af den symbolsk overførte kønsdualisme, der udspringer af tendensen til at tænke i binære møn- stre. Mænd og kvinder konstrueres som kategorier, der udelukker hinanden: En person kan kun have et køn, aldrig det modsatte og aldrig begge. Ifølge Flax (1987) producerer mænd og kvinder køn, men de er også fastholdt af det. Virkeligheden konstrueres i overensstemmelse med dikotomien og polariteten mellem maskulin og feminin. Massemedierne spiller en betydelig rolle i præsentationen og reproduktionen af kønsstrukturerne. Køn har imidlertid ikke kun en institutionel, men også en individuel side; det er forankret i individernes identitet og image.

\section{DOING GENDER}

Hvordan bliver det sociale køn indlejret i menneskets krop og sind, og hvordan konstrueres og rekonstrueres mænds og kvinders køn kontinuerligt som en institution? Mennesket kategoriseres som tilhørende en social gruppe og opdeles yderligere efter deres køn via deres fysiske fremtoning som tøj, frisure, måden de bevæger sig på og kropssprog - og dette sker som regel ubevidst. Selvom det, der bliver betragtet som typisk for en mand eller en kvinde, ændres alt efter den kulturelle kontekst, så er det stort set fast defineret. Enhver afvisning af en kategorisering med henblik på ens køn eller af det at opføre sig 'ordentligt' i overensstemmelse med ens køn bliver mødt med fordømmelse. Man skal bare tænke på sin egen utilpashed, når man ikke er i stand til at genkende en samtalepartners køn. Et af de vigtigste kendetegn for kønnet er tøj, da det gør kønsforskellene visuelt tydelige. Eksemplet med tøj demonstrerer ikke kun, at den symbolske kønsforskel er indlejret i kulturen, men også at den er foranderlig, og at der ikke er nogen logisk sammenhæng mellem tegnet, dvs. tøjet, og dets betydning, dvs. kønnet. Derfor er det i den ene kultur mændene, som 'har bukserne på', bogstaveligt såvel som symbolsk, hvorimod det $\mathrm{i}$ andre kulturer udelukkende er kvinderne, som går med bukser. 


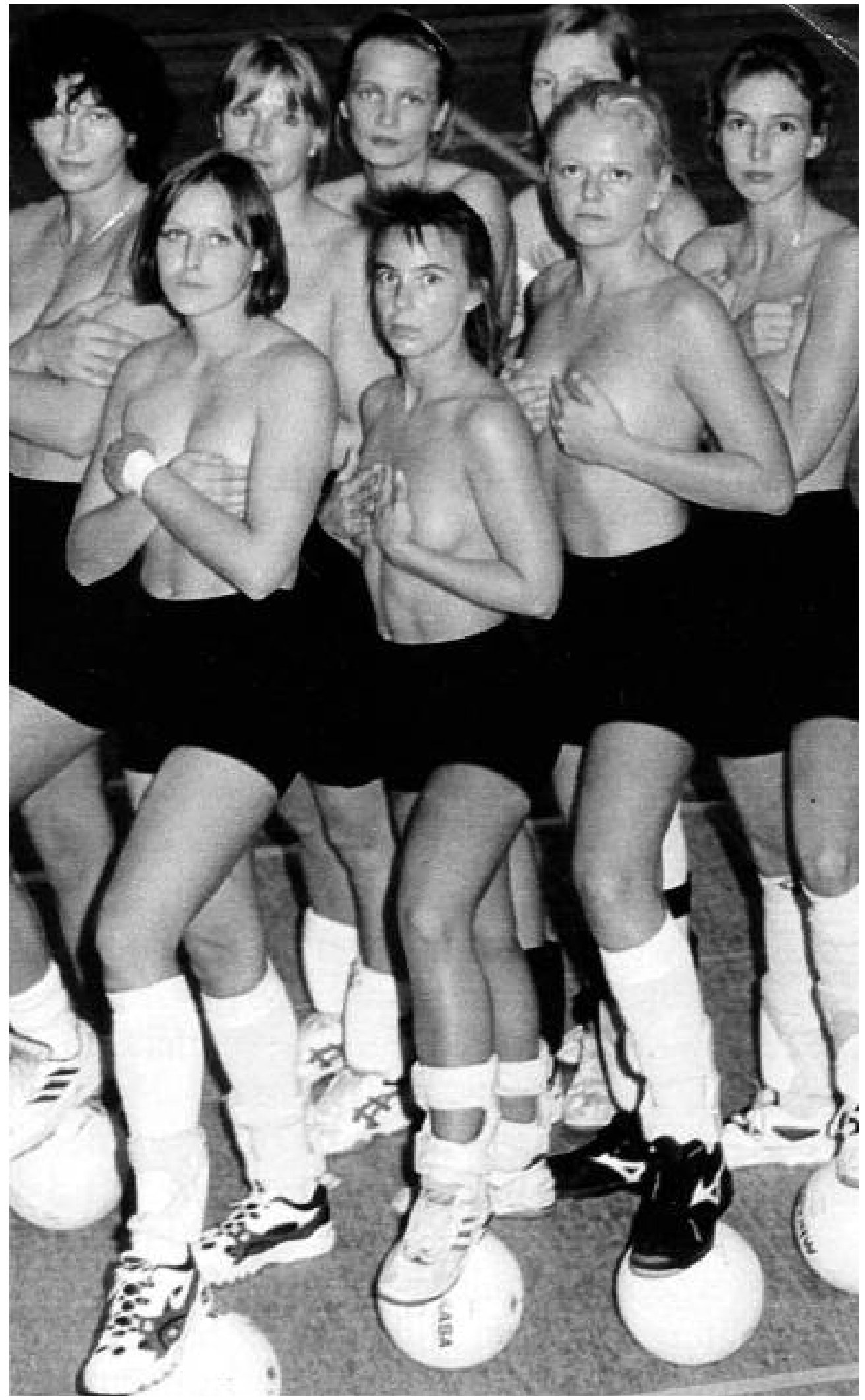


Køn er derfor ikke noget vi er eller har, men noget som vi producerer og gør. "Gender is constantly created and re-created out of human interaction, out of social life, and it is the texture and order of that social life ... it depends on everybody constantly doing gender" (Lorber 1994, 13). "Gender is both something we do and something we think with. Both a set of social practices and a system of cultural meaning" (Rakow 1986, 19). Køn er en aktiv handling.

\section{DOING GENDER I SPORT}

Sport er en fysisk aktivitet, som indebærer en præsentation af kroppen og en demonstration af fysisk udfoldelse, og det er et af de få områder i vores kultur, som har en streng kønsopdeling med forskellige regler, reguleringer og normer for henholdsvis mænd og kvinder. Sportsdiscipliner betegnes som mandlige og kvindelige, og de skaber en perfekt mulighed for at vise maskulinitet igennem fysisk styrke, udholdenhed, kraft og aggressivitet eller femininitet igennem ynde og elegance. Derfor er sportsudøvere altid udøvere af socialt køn, og de forskellige former for sport er forbundet med forskellige kønsidealer og budskaber. ${ }^{3}$ Den kønsbestemte sportskultur, som er specifik for hver enkelt sportsgren, er ikke kun skabt af traditioner, image eller miljø (fodboldmiljøet er et mandemiljø), men udøves også af deltagerne og korresponderer med deres selvopfattelse.

At gøre køn i sport er ikke kun noget de kvindelige udøvere gør; tværtimod er sportens momenter af fysisk styrke og fysisk præstation, såvel som konkurrencemomentet og aggressiviteten vigtige maskuline markører.

Sport er imidlertid en social sfære, hvor køn ikke kun bliver skabt, men også xndret. Mens tidligere studier har undersøgt, hvilke konflikter de kvindelige sportsudøvere på grund af deres køn har oplevet i mandlige sportsgrene, har nyere studier lagt større vægt på, at kvinder ved at vælge sportsgrene som bodybuilding eller boksning yder en større modstand mod konstruktionen af køn. Et resultat heraf kan blive, at det bliver muligt at genopdage og ændre konstruktionen af køn og kønsrollemønstrene (Denfield 1997, Heywood \& Dworkin 2003).

Medierne er en del af kønsopdelingen; de skaber kønsidealer og tilbyder kønsmæssige drejebøger. De er magtfulde agenter for socialiseringen. Deres drejebøger svarer til udøvernes præsentation af sig selv og til deres måder at gøre køn på.

\section{SPORTENS UDVIKLING OG \\ MASSEMEDIERNES ROLLE}

Dækning af sport i massemedierne og markedsføringen af sportsudøvere har fulgt bestemte mønstre, som har forandret sig sideløbende med de sociale forandringer, der er sket i løbet af det 20. Århundrede. Massemedierne opdagede sporten i 1920erne, men sportsreportager blev hovedsagligt skrevet af mænd til mænd og handlede om mandesport. Sporten havde brug for massemedierne for at kunne opnå offentlighedens opmærksomhed, legitimering og derved også dens støtte. Medierne brugte sport som et produkt med høj informations- og underholdningsværdi. Efter Anden Verdenskrig blev båndet mellem medierne og sporten meget stærkere, og sport blev et vigtigt fokuspunkt og en central del af det skrevne medie, radioen og senere fjernsynet. Udviklingen af sport og mediasport blev i høj grad påvirket af den Kolde Krig, da $\varnothing_{\text {st }}$ og Vest brugte sporten som en metode til opnåelse af prestige, politisk indflydelse og magt.

Efter en periode, hvor kvinders fysiske aktivitet stadig var orienteret mod de traditionelle roller og idealer, oplevede de kvindelige sportsdiscipliner, især inden for elitesporten, et opsving, blandt andet fordi sport - også kvindesport - blev brugt som et våben $\mathrm{i}$ den Kolde Krig. USSR's deltag- 
else ved De Olympiske Lege i 1952 blev starten på en ny æra inden for de kvindelige sportsdiscipliner, især fordi de sovjetiske sportsudøvere udførte præstationer, som tidligere var blevet anset for farlige og/eller uopnåelige for kvinder. Dog koncentrerede medierne sig også i denne periode om de mandlige sportsdiscipliner, især om fodbold.

En indholdsanalyse af Frankfurter Allgemeine Zeitungs (FAZ) dxkning af De Olympiske lege i perioden 1952-1980 viser den udvikling og de forandringer, som er sket i måden, hvorpå medierne rapporterer om sport og udøverne. Et af resultaterne var, at reportagerne fra 1950erne og 1960erne koncentrerede sig om sportsbegivenheder, den sportslige præstation og var ret neutrale. 4

På dette tidspunkt havde sportsudøverne - i hvert fald de fleste af dem - ikke selv nogen indflydelse på, hvordan de i medierne blev beskrevet som personer. Dette kan forklares ud fra den daværende situation: Udøverne var amatører. Elitesport var mere eller mindre en frivillig fritidsaktivitet, i hvert fald sammenlignet med nutidens træning, sportsudøvere havde et 'uniformt image' (tøj), og pressen fremstillede dem som naboens sønner. Kvindelige sportsud$\varnothing$ vere og kvindelige sportsdiscipliner var marginaliserede, hvilket også hang sammen med, at kvinder stadig var ekskluderet fra mange typer sport (i 1968 var kun $21 \%$ af disciplinerne ved De Olympiske Lege åbne for kvinder).

\section{Fra gyMNASTIKPRINSESSER TIL FLO JO - SPORT OG MASSEMEDIERNE FRA 1970ERNE TIL 1990ERNE}

Som vist ovenfor i indholdsanalysen af FAZ ændrede dækningen af sportsbegivenheder sig afgørende i 1970erne: Andelen af personhistorier steg, og der opstod en stor forskel på måden, hvorpå henholdsvis mænd og kvinder blev fremstillet. $\mathrm{Nu}$ koncentrerede pressen sig hos de kvindelige sports- udøvere om de personlige historier, men hos de mandlige fokuseredes der på sportsbegivenhederne. På samme tid blev de kvindelige udøveres fremtoning vigtigere. I dækningen af De Olympiske Lege i 1980 indeholdt $50 \%$ af reportagerne om kvindelige sportsudøvere informationer om deres fremtoning, mens sådanne informationer kun forekom i $20 \%$ af reportagerne om mandlige udøvere. Journalisterne beskrev entusiastisk de kvindelige sportsfolks blonde hår eller lange ben. For eksempel beskrev FAZ De Olympiske Lege i 1972 som en skønhedskonkurrence. De kvindelige udøvere, som ikke levede op til kravet om skønhed og ynde, blev beskrevet som ukvindelige, og kvindelige muskler blev på dette tidspunkt anset for uattraktivt eller grimt. Resultatet af mit førnævnte studie støttes af en analyse af en af de mest populære boulevardaviser, Bild Zeitung, som jeg foretog i 1980. Kvindelige sportsdiscipliner var stadig et marginalt emne og udgjorde kun 5\% af dækningen (Klein/Pfister 1985). Dertil kommer, at kvindelige sportsudøvere blev fremstillet som 'det andet køn', og journalisterne havde mange forskellige metoder til at marginalisere dem. Kane og Greendorfer karakteriserer fremstillingen af kvindelige udøvere som "symbolsk udslettelse" og "karikeret kvindelighed". 5 Derved producerede og reproducerede medierne kønsidealerne og kønsforskellene.

I 1980erne begyndte sportsudøverne selv at spille en vigtig rolle i markedsføringen; som professionelle var de nødt til at udvikle deres fremtidsperspektiver, og det gjorde de ved at sælge deres præstationer. Opskriften fra 1980erne var: Stærk præstation, attraktivt udseende og et interessant image. Et godt eksempel for denne type udøver er Florence Griffith Joyner (Flo Jo), som vandt tre guldmedaljer i 1988, og som overraskede tilskuerne med sit ekstravagante tøj.

Der kan identificeres adskillige grunde til ændringen i sportsudøvernes image og fremtoning: Det stadig højere præstations- 
niveau medførte en forøgelse af træningens omfang og intensitet og en professionalisering af udøverne, trænerne etc. Som konsekvens heraf var man nødt til at afskaffe den olympiske amatørvedtxgt i 1981. Store præstationer styrkede fascinationen af sport, hvilket forøgede vigtigheden af sportsreportager, som igen skabte en stigende sportsinteresse hos offentligheden. Dette var begyndelse på en aktiv markedsføring af sport og af sportsudøvere, og nu var det ikke kun information om sporten, som var vigtig, men også historier om udøverne, der som formål havde at underholde og give muligheder for identifikation og derved øge antallet af læsere (og købere).

Presset på det skrevne medie for at markedsføre deres produkt - nyheder om sport - voksede i takt med den stigende konkurrence fra fjernsynet. En af avisjournalistens vigtigste strategier blev at tilfredsstille offentlighedens nysgerrighed og identifikationsfantasier ved at fodre dem med informationer om deres sportshelts privatliv.

\section{BIKINIER, NØGNE SPORTSUDØVERE OG SPORTSLIGE PRÆSTATIONER - SPORT SOM ET MARKED}

I 1990erne ændrede billedet sig igen. At gøre køn i gymnastiksalen og på sportsarenaerne fik en ny og anderledes drivkraft, men tendenserne var ambivalente. Et nyt longitudinalstudium fra The Amateur Athletic Foundation i Los Angeles (AAF) omkring "Gender in Televised Sports" i USA viste at: "In 1989 women's sports received only 5\% of the coverage. The 1999 numbers show an insignificant increase to $8.7 \%$. What coverage does exist still too often treats women not as athletes, but as sex objects." IOC-medlem, Anita L. DeFrantz, kommenterede resultaterne af studiet som følger:

"There is a name for a pattern of behaviour that ignores and belittles women's accomplishments. It is sexism, plain and simple"6
Lignende resultater kan findes i mange lande verden over, og problemet omkring den uretfærdige og ufuldstændige dækning af kvindesport vises $\mathrm{i}$ mange af bidragene til en bog om Women and Sport. International and Comparative Perspectives (Hartmann/ Pfister 2003). Medierne fortsætter med at skrive forskellige drejebøger for mandlige og kvindelige sportsudøvere, og mediernes dækning afspejler tydeligvis samfundenes opfattelse af køn. Dog er vi nødt til at differentiere mellem de forskellige medier; og til at være opmærksomme på, at der kan findes seriøse og interessante sportsreportager i den 'seriøse' presse. Overordnet er der dog en tendens inden for sportens udvikling, som bevæger sig hen imod boulevardisering og sensationalisme i forbindelse med sport, og en seksualisering af udøverne er en del af denne trend.

Billeder fra De Olympiske Lege i Sydney viser tydeligt, at kroppen bliver mere og mere eksponeret - bikinier eller txtsiddende tøj viser 'alt'. I De Olympiske Lege i dag er det ikke kun gymnasterne, men også mange andre sportsudøvere, fra løbestjernerne til beachvolleyspillerne, som optræder meget lidt påklædte. Hvordan skal vi vurdere denne nye dress code, denne xndring i måder at gøre køn på? Hvilke intentioner og motiver har udøverne? Hvordan er denne nye præsentation af kroppen og måder at gøre køn på forbundet med den nye udvikling inden for sport og med integrationen af kvinder i det, der tidligere var mændenes domæner?

I dag accepteres kvinder i flere og flere sportsgrene, som kræver styrke, hårdhed og udholdenhed, lige fra maraton til boksning og vægtløftning. Muskler er ikke længere noget, som er i modstrid med det tiltrækkende feminine, og de kvindelige udøvere er tydeligt stolte af deres kroppe. Endringen af kroppens idealer og sportsudøvernes image er emne for en ny bog, Built to win, som er skrevet af Heywood and Dworkin (2003). Forfatterne beskriver det fænomen, at stærke og selvsikre sportsfolk som fod- 
boldspilleren Mia Hamm eller basketballstjernen Lisa Leslie er blevet kvindelige ikoner over hele USA.

Denne trend kan også ses i de legemliggjorte drømmes verden, i reklamerne. Et godt eksempel på den ændring, der er sket inden for drejebøger for kønnene, og brugen af de nye typer og idealer for kompetente og succesfulde kvinder i reklamer ses i Nike-reklamerne. Nike fokuserede et godt stykke ind i halvfemserne på mænd som deres primære publikum, før de opdagede kvinderne som en potentiel kundegruppe og udviklede nye reklamestrategier, som var specielt designet til kvinder. Den nye type reklame overraskede mange, fordi den sympatiserede med kvinderne og stillede sig på deres side. En af reklamerne havde titlen If you let me play og brugte følelsesladede billeder til at fremme kvindesport og derved give alle kvinder en chance for at deltage $\mathrm{i}$ sport og på den måde dele de fordele, som sporten giver.

Da undersøgelser i midten af halvfemserne således viste, at Nike-reklamer ikke appellerede til kvinder, fordi disse forbandt Nike med mandesport, xndrede firmaet sin strategi og begyndte at inddrage kvindelige sportsstjerner som fx Mia Hamm med henblik på at give piger og kvinder mulighed for identifikation. Dermed satte Nike fokus på kvinder, der ikke var afhængige af det mandlige blik, og som blev præsenteret som sportsudøvere, ikke som fantasikvinder. Således blev Mia Hamm fx ikke introduceret som "den bedste kvindelige fodboldspiller", men simpelthen som "den bedste fodboldspiller" (Goldmann/Papson 1998, 141)

I mellemtiden har Nikes hovedkvarter dog ændret kurs, fordi reklamerne med elitesportskvinder åbenbart ikke medførte den ønskede stigning i omsætningen. Kvinder identificerer sig åbenbart ikke på samme måde som mænd med sportsstjerner. Den nye strategi fokuserer på kvinders kondition og fritid: "We needed to listen to women when they said: 'I am not a runner, I just run"'.7 Det ene aspekt af Nikes markedsføring er altså superudøverne og 'de stærke kvinder' - det andet er de stereotypiserede og seksualiserede billeder af kvinder - og mænd.

Generelt kan vi observere, at kvindelige udøvere skal holde sig inden for den 'etablerede femininitet', og at de skal bevare balancen mellem det androgyne og det seksuelt attraktive, hvis de vil accepteres af det brede publikum. Kvinder, der er for muskuløse eller ikke passer ind under reglerne for kønnets dualitet og heteroseksualitet, bliver ikke accepteret.

\section{KOURNIKOVA-SYNDROMET}

Og der er en ny trend under opsejling: Kournikova-syndromet er på vej. Hvad mener jeg med Kournikova-syndromet? Anna Kournikovas popularitet er primært baseret på hendes udseende og image, hendes sportslige præstationer spiller kun en sekundær rolle. Og dette er noget helt nyt: Op til 1980erne var kvindelige sportsudøvere blevet berømte på grund af deres sportslige præstationer, og deres attraktivitet var så en ekstra fordel. Kournikova har aldrig vundet en stor (WTA) turnering, og hun er ikke blandt de bedste spillere. Men hun er uden tvivl, selv nu efter at have trukket sig tilbage, nummer et med henblik på indtjening. I 1999 tjente Kournikova cirka 700.000\$ på tennisbanen, men hendes samlede indtjening var over 15 millioner \$. Anna Kournikova bliver af medierne beskrevet som "the best paid mannequin", 8 en opmuntring for mænd, tennisens Lolita. 9

Hvis sportsudøverne bruger deres udseende som salgsvare, er de nødt til at tilpasse sig de samme regler og strategier, som gælder for showbusinessstjerner. De skal være til stede ved fester, events og talkshows. Det berømte tyske blad Der Spiegel diskuterer i mange, mere eller mindre kritiske artikler sportsstjerners glamourøse verden og deres nye strategi, der bl.a. går ud på, at 
"være til stede alle vegne - men uden at have noget at sige". Følgelig er de kvindelige sportsudøvere også nødt til at præsentere sig selv som 'play girls' og til at posere nøgne eller halvnøgne for medierne. Anna Kournikova er ingen undtagelse, men derimod forløberen for denne stadig mere populære trend. I Tyskland er Magdalena Brzeska, en internationalt ukendt gymnast, og Tanja Sewzenko, en ikke særlig succesfuld kunstskøjteløber, stadig - mange år efter at de har droppet elitesport - populære på grund af deres udseende og marketingsstrategier. Begge har smidt tøjet i Playboy. ${ }^{10}$ I Danmark er det muligt bl.a. i Copenhagen Post at beundre badmintonstjernen Camilla Martin i sexede positurer. ${ }^{11}$

Selv succesfulde udøvere bruger deres udseende til at fange publikums opmærksomhed og til at blive stjerner med alle de muligheder for penge og glamour, dette giver. Der er talrige eksempler: Brandi Chastain, fodboldspiller på det amerikanske VM-landshold, blev fotograferet i Gear Magazine $^{12}$ kun iklædt en fodbold, og den tyske skøjteløber Anni Friesinger smed alle hæmningerne og viste sig selv i "al sin skønhed" (Stern, 2001, 6, 75 ff.).

Et andet godt eksempel inden for denne nye trend er den tidligere advokat og nuværende verdensmester i boksning, tyskeren Regina Halmich, som besluttede sig for at tjene penge på en lettere måde end ved at bokse. Efter at have vundet en arrangeret kamp imod den 'kendte' tyske studievært Stefan Raab (hvor hun brækkede hans næse), blev hun fejret af sensationspressen som en glamourøs starlet. Hun præsenterer sig selv på internettet som "smuk og sexet" og har i mellemtiden skabt sin egen kosmetikserie. ${ }^{13}$

Kommodificeringsprocessen har fået en ekstra skub igennem internettet med dets uanede muligheder. Der findes et stort antal hjemmesider med informationer om kendte sportsfolk, også Kournikova-sider, hvor man kan se hendes resultater og hendes biografi, samt billeder. På internettet kan man købe bøger, kalendere, fotografier etc. af Kournikova. Det er endda en computervirus, som er opkaldt efter Anna Kournikova (Tagesspiegel, 14. februar, 2001, 30).

Hvad sælger Anna Kournikova ud over sig selv? Hvordan bruger hun sit navn, sit image og sin femininitet til reklamer og reklameprodukter? Ligesom mange andre sportsudøvere, som tjener på sporten ved at være et 'big symbol', så har Anna Kournikova en multifunktion og udsender mange forskellige signaler. Ikke mindst fordi hun præsenterer sig selv som en, der leger med kønsskabte billeder og symboler, kan hun bruges inden for reklamer for mange forskellige produkter: fra en sports-BH med sloganet "only the ball should bounce" til sportssko, elegante ure og mobiltelefoner. Kournikova praktiserer helt klart doing genderat gøre køn og præsenterer sig selv som en fantasikvinde for det mandlige blik, både på og uden for tennisbanen; for eksempel imiterede hun Marilyn Monroe i en reklame for Adidas tennissko.

Markedsføringen af Kournikova er ikke kun accepteret, men også højt skattet af Tennisforbundet, hvis officials håber, at hendes popularitet vil kunne kompensere for offentlighedens faldende interesse for tennis. Donna A. Lopiano, ledende direktør for Women's Sports Foundation, forventede, at Anna Kournikovas aktiviteter ville medføre et opsving inden for tennis, men udtrykte dog et enkelt forbehold eller håb: "If only Anna Kournikova could win the Open and appear in Sports Illustrated with her clothes on."l4 Forbundene såvel som organisatorerne bag sportsbegivenheder ved, at i dag tæller skønhed mere end præstation. Derfor eksisterer der en uofficiel verdensrangliste for kvinder, og Anna Kournikova var placeret øverst. Som Nathalie Tauziat (2000) skriver i sin provokerende bog; Les dessous du tennis feminin (kvindetennisens undertøj), så făr topstjernerne på den uofficielle liste ikke kun flere penge end andre, men har også en fordel 

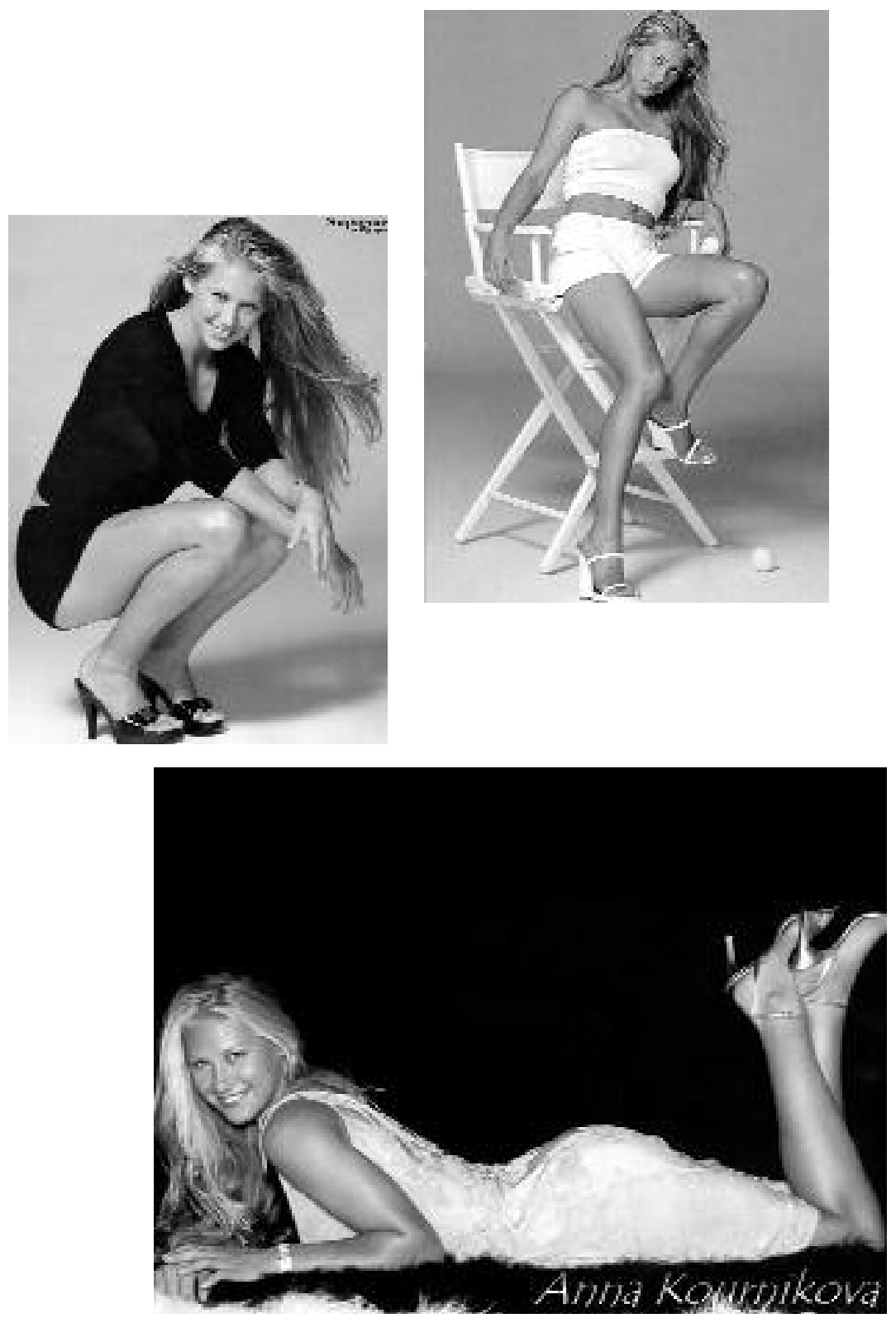
med henblik på tidspunktet og stedet for deres kampe.

Anna Kournikova har stoppet sin tenniskarriere, men Kournikova-syndromet fortsætter og spredes. Som supplement til nøgenfotografering er de nyeste tendenser konstruktionen og fremførelsen af hele fortællinger omkring kvindelige sportsudøvere. Et godt eksempel er 'krigen imellem primadonnaerne' inden for skøjtesporten i Tyskland. Massemedierne skildrer skøjteløberne Anni Friesinger og Claudia Pechstein som rivaler, der hader hinanden, og det hele kunne, ifølge Spiegel (2004, 11, 145), minde om set-uppet for et realityshow. Anni Friesinger satser på sin krop, især på sine bryster, som hun gerne viser frem - mere eller mindre tildækkede. I en pressemeddelelse offentliggjorde hun, at hun var nødt til at bruge en dobbelt $\mathrm{BH}$ for at tøjle sin barm. Og mens Anni Friesinger imiterer den 'sensuelle forfører', så personificerer Claudia Pechstein snarere den 'frække karrierekvinde'. Medierne udpenslede især historierne om "BH-misundelse" og "katte-slagsmål", da de to rivaler skulle konkurrere mod hinanden. Ud af en sportskamp skabte de et melodrama, som lokkede millioner af tilskuere hen foran fjernsynet. Drejebogen til "tøsekampene" skrives af mænd, udøvernes managere, som sælger sportslig succes til reklameagenturer ved hjælp af personlige historier og sex - og dermed spinder guld på dem. Derfor spiller det heller ikke nogen rolle, at et interview med Friesinger nødvendigvis må være "emnemæssigt begrænset", fordi hun "ikke reflekterer over særligt meget". 15

Nutidens markedsføring af sportsfolk, mediernes presentation af dem og deres måder at gøre køn på kan summeres op på følgende måde: I det sidste årti har idealerne for kvindelighed forandret sig inden og uden for sport. Kvinder er mere og mere orienteret mod et androgynt ideal, og kvindelig styrke og attraktivitet modsiger ikke længere hinanden. Ikke desto mindre prøver kvindelige sportsudøvere i deres sel- vpræsentation at fokusere på både det sportslige og det feminine på en og samme tid. Massemedierne bruger udøvernes selviscenesættelse, og de konstruerer kønsbestemte billeder, historier og imager. Og ofte følger disse sloganet: sex sælger. Derfor har udseendet og iscenesættelsen af kønnet højere prioritering i dag end tidligere. Anna Kournikova repræsenterer kun én trend inden for sport og udviklingen i sportsmedierne. Der er også eksempler på sportsfolk, som fører sig frem som stærke og kompetente. De er dog nødt til at tilpasse sig de fremherskende idealer for ikke at blive betragtet som outsidere.

Venus og Serena Williams er Kournikovas modsætning. De er sorte, meget talentfulde og succesfulde tennisspillere, og mediernes billede af dem bærer præg af en kombination af og en vekselvirkning mellem køn, race og sport. Deres 'sorthed' i en 'hvid sport' såvel som den styrke og aggressivitet, som de synes at udstråle, gør dem som kvinder anderledes end andre kvindelige tennisspillere. Denne forskel fremhæves af medierne i deres beskrivelser af Williamssøstrene som fx "kæmper”, “skræmmende", "sværvægtsboksere" og "Predator Et og To". Idet medierne følger en racemæssig logik, beskrives søstrenes præstationer som “sportsmæssig naturlig”. Deres særprægede frisurer og tøj bliver også tit diskuteret. "Disse beskrivelser styrker opfattelsen af søstrene som uvedkommende, hvis tilstedeværelse underminerer den kulturelle integritet inden for kvindetennis". 16 Inden for det sidste år har Kounikova-syndromet ramt Williamssøstrene, og medierne har rettet deres fokus mod især den yngre søster Serenas udseende og seksuelle udstråling.

Man kan spørge: Hvad med mænd? Er de ikke udsat for et lignende pres? Ja og nej. Hvor kvindelige sportsudøvere stadig oftere fremstiller sig selv som sexobjekter, så præsenterer størstedelen af de mandlige udøvere sig som sportsudøvere i sportstøj eller i bevægelse. Deres image som sports- 
folk og deres maskulinitet rummer ingen konflikter, tværtimod bliver deres maskulinitet forstærket igennem sporten. Dertil kommer, at de mandlige sportsudøvere har flere muligheder for at tjene penge end kvinderne. Det er også af betydning, at de fleste sportstilskuere er mænd, og at de mandlige udøvere derfor skal tilpasse sig de forventninger, som et homofobisk mandspublikum har. Men nogle mandlige udøvere har opdaget deres erotiske image, og også de har en tendens til at fremvise deres kroppe og attraktivitet. Dette gxlder for Dennis Rodman såvel som David Beckham, for skihoppere såvel som fodboldspillere $\mathrm{i}$ Bundesligaen. ${ }^{17}$ I modsætning til kvinderne kan de mandlige sportsfolk imidlertid også profitere på et 'bad guy'-image. Et godt eksempel på dette er Kobe Bryant, som er blevet beskyldt for at have voldtaget en hvid hotelstuepige. Spiegel (2004, H. 8, 53 ) formoder, at et "Gangster-rapper" image vil forhøje hans popularitet og dermed få hans markedsværdi til at stige.

\section{KOMMODIFICERING AF SPORTSUD ØVERNE - BAGGRUND OG ÅRSAGER}

Globaliseringen af den moderne sport og dens stadig større politiske, sociale og økonomiske betydning kan ses i sammenhæng med et stadigt stigende præstationsniveau, der kan aflæses af verdensrekorderne, og en voksende konkurrence mellem nationer, hold og sportsudøvere. Dette kræver en stigende indsats med henblik på omfanget, intensiteten og logistikken omkring træningen. Derfor må man som sportsudøver søge andre finansielle kilder end staten frem for alt sponsorer. Elitesport er derfor blevet til en eliteforretning - en vare, som skal 'sælges' til mere og mere kræsne sponsorer og tilskuere, som lader sig tryllebinde af store begivenheder og stjerner. Begivenheder og stjerner er salgbare og sælges, men udøverne er kun stjerner, hvis de formår at vække opsigt, hvis de har et spænd- ende image, hvis de kan ramme det etablerede publikums smag, og hvis de udgør identifikationsmodeller.

I dag er det ikke nok at være en olympisk medaljevinder, man skal også have salgbare kvaliteter. Marketing af sportsudøvere er især blevet vigtig inden for sportsgrene, hvor der skal kæmpes for offentlighedens interesse, og dette er også tilfældet med tennis. (Tagesspiegel 11. oktober 2000). Derfor leder sportsagenter efter flere Kournikovaer mellem 12-årige tennisspillere; og det er ikke kun talent, som er et vigtigt udvælgelseskriterium, men også udseende og opførsel. (Der Spiegel, 2001, 7, 177 ff.).

Massemedierne er også under pres. De er tvunget til at sælge deres produkter, og den indbyrdes stigende konkurrence bliver mere og mere heftig, blandt andet på grund af internettet, som støtter globaliseringen af information. På TV-området, hvor der er mange konkurrerende kanaler, kæmpes der hårdere og hårdere for at vinde seerne, og på samme tid er der en stigende hunger efter sensationer, men også efter intimitet og autencitet. Et godt eksempel på seerens smag og aftabuiseringen af privatlivet er de såkaldte reality shows, hvor 'normale' mennesker fx skal opholde sig på en øde $\varnothing$ i fire uger, og hvor deres aktiviteter, relationer og reaktioner så kan blive genstand for seernes nysgerrighed. Også sportsudøvere er objekter for den kollektive voyeurisme.

Ud over dette kan det antages, at medierne fokuserer på de kvindelige sportsudøveres attraktivitet og seksualitet for at kompensere for deres styrke og succes inden for sport. Budskabet kunne være at: Kournikova er en god tennisspiller, men hendes udseende er meget vigtigere. Derfor bliver kvindernes prestationer devalueret, og dermed opstår der en ny form af myten om det smukke køn.

\section{SPORTSUDØVERE OG DOING GENDER}

Det er svært at bedømme den rolle, som 
udøverne spiller i denne udvikling. For det første skal det pointeres, at kvinderne selv tager aktivt del i opbygningen af et bestemt image og i markedsføringen af det. Kvindelige sportsfolk er ikke ofre (i hvert fald ikke umiddelbart), men aktører, som på mange måder er afhængige af samfundet, men som også har mulighed for at påvirke beslutninger og udvikling. Med henblik på de kvindelige udøveres måder at gøre køn på kan der stilles mange spørgsmål: Hvad er deres budskab, når de præsenterer sig selv på en seksuel måde? Hvorfor gør de dette? Hvordan tolker tilskuerne det? Hvilken rolle spiller nyt tøj som bikinien i beachvolleyball - er det en befrielse af kroppen eller seksualisering?

Der er ingen litteratur eller forskning til rådighed på dette område, og vi har ikke noget sikkert og begrundet svar på disse spørgsmål. Derfor kan der kun opstilles nogle enkelte teser, som handler om de kvindelige udøveres situation. I dag påvirker følgende faktorer elitesportens udøveres situation:

Elitesport er, som nævnt tidligere, blevet et fuldtidsjob, hvilket tit umuliggør en uddannelse og kan ødelægge ens fremtid (skader, helbredsproblemer). Derfor er der et stadigt stigende pres på udøverne med henblik på at sælge deres image og på at tjene så mange penge som muligt. På samme tid er incitamentet, den potentielle indtjening, steget til astronomiske højder. Udøverne kan bruge sportsarenaen som et perfekt podium til at blive kendte, populære, til at iscenesætte deres køn og sælge sig selv. På den ene side så kan sportsudøverne tilbyde en perfekt krop og har rig mulighed for at vise deres kroppe på en mere eller mindre erotisk måde, på den anden side forventer og værdsætter forbrugeren (og de fleste sportstilskuere er mænd) erotiske images. "Sex sælger bedre end præstationer", pointerer en af Tysklands største sportsmagasiner Sport Bild (2000, 25, 55). Det skal også tages med i betragtning, at det kan være ret fantastisk for en ung sportsudøver af få offentlighedens opmærksomhed. "It's every girls fantasy to be a sex symbol" (US swimmer Ashley Tappin). ${ }^{18}$ Sandheden i dette kan dog diskuteres. Udøverne har imidlertid mange grunde til at spille den rolle, der forventes af dem.

\section{EVALUERING OG REAKTIONER}

Hvilken effekt har denne udvikling? Hvad betyder dette for kvinder, for sport og for samfundet? I den ovennævnte internetdiskussion stod der ikke kun moralske problemstillinger til debat - også kvindesportens perspektiver og spørgsmålet om magt blev diskuteret. En sportssociolog forbandt kvindelige sportsfolks fremtoning med en kamp om magt og kontrol: "When it comes to using nudity to get attention, the physical prowess and athletic accomplishments become secondary. There is power in having control over one's body and using her to succeed in the world of sports. When nudity is the foremost image, the strength and sovereignty of the athlete is no longer the primary focus. Nudity is one aspect of determining who controls a woman's body: does the athlete or the marketplace?". 19

I denne debat blev det klart, at seksualiseringen af de kvindelige sportsfolk og brugen af sex som et vigtigt kriterium $\mathrm{i}$ bedømmelsen af de kvindelige udøvere skader kvinder og kvindesport. Leslie Heywood (2004) afviser fra et postfeministisk perspektiv de moralske argumenter og pointerer, at præsentationen af kvindelige bodybuildere som sexobjekter kompromiterer både de kvindelige udøvere og sporten.

The Women's Sport Foundation kom med følgende udtalelse omkring fremstillingen af mandlige og kvindelige sportsudøvere $\mathrm{i}$ medierne: Hvis medierne præsenterer kvinderne som sexobjekter og mændene som stjerner, så er det "en dobbeltmoral, der gør kvinder til objekter. Eftersom Sports Illustrated sjældent dækker kvinders sportsli- 
ge præstationer og ofte portrætterer kvinder som sexobjekter snarere end sportsudøvere, er dets dækning anstødelig og nedgørende over for kvindelige sportsudøvere... Den mandlige eller kvindelige sportsudøvers beslutning om at optræde nøgen eller halvnøgen i dette magasin (Esquire, red.) virker tilbage på hans/hendes image. Ønsker han/hun at blive husket som sportsudøver eller som nøgenmodel? Eftersom dxkningen af kvindelige sportsudøveres præstationer i de skrevne og elektroniske medier er $80-90 \%$ mindre end dækningen af mændenes, giver kvindelige sportsudøvere, der benytter denne mulighed for ikke-sportslig udstilling, medierne tilladelse til at fortsætte deres marginalisering af kvindernes sportslige præstationer." Udøverne burde reflektere over den måde, de fremstiller sig selv på. "Der er mange måder, hvorpå kvinder vælger at 'kræve deres krop tilbage' efter at være blevet fremstillet som objekter i medierne i så mange år. At fremvise deres styrke og deres muskler er en af måderne, og denne er rosværdig. Mandlige og kvindelige sportsudøvere kan gøre dette i en minimalistisk sportspåklædning (badedragt, compression shorts, sports-BHer) og i autentiske sportspositurer uden at fremvise eller forsøge at fremhæve genitalier på 'sexede' måder. ${ }^{20}$

Udtalelsen fra Women's Sport Foundation tager de kvindelige idrætsudøveres sportslige præstationer alvorligt og tillader et stort spillerum for deres fremtræeden, uden at løfte moralske pegefingre. De idrætsansvarlige bør imidlertid også betænke, at selvom nøgenhed og seksualitet i og uden for idrætten er blevet aftabuiseret i den vestlige verden, så bliver letpåklædte idrætskvinder opfattet som anstødelige $\mathrm{i}$ andre kulturer. Derfor må beklædningsforskrifterne i det mindste gestaltes på en måde som muliggør deltagelse af kvindelige idrætsudøvere fra den islamiske kulturkreds.

Såvel kvindelige idrætsudøvere som massemedier og idrætsorganisationer har indlysende nok hver deres egennyttige interes- se $\mathrm{i}$ at stille erotisk attraktivitet til skue, men de bør også have en fælles interesse i sportens og idrætsudøvernes integritet.

\section{NOTER}

1. "FWS" FWS@listbot.com Emne: Kournikova og SI. Dato: fredag. 16. juni 2000 11:01:13 -0700.

2. Lorber (1994).

3. Se Klein (1997), Hartmann \& Rulofs (1998).

4. Pfister (1999)

5. I Duncan, Williams \& Messner (1991, 34), Kane \& Greendorfer (1994); se desuden forskellige bidrag i Creedon (1994).

6. "Gender in Televised Sports" se http://www.aafla.org/Publications/Publications.htm.

7. Warner, Fara: Nike's Women's Movement, august 2002, http://www.fastcompany.com/magazine/61/nike.html; se Goldman \& Papson (1998).

8. DSB-Presse (29.2.2000), DSB = Deutscher Sportbund, se endvidere Tauziat (2000).

9. Sport Bild (2000, No. 25, 55). Omkring dækningen af kvindelige sportsudøvere i Sports Illustrated se Davis (1997).

10. Der Spiegel 1997, Nr. 52, 196.; se også Der Spiegel 1997, Nr. 37, 121

11. Copenhagen Post, 19 - 25 marts 2004, 12.

12. http://espn.go.com/page2/s/questions/ chastain010618.html.

13. http://www.regina-halmich.org.

14. Donna A. Lopiano, ledende direktør for Women's Sports Foundation, indsendt til to Sports Business Journal (august, 2000).

15. Kunstskøjteløbernes marketingsstrategi er sammenfattet i Der Spiegel 2004, H. 11, 144-146.

16. Douglas (2002), http://physed.otago.ac.nz/ sosol/v5i2/v5i2_3.html

17. Om skihopperne m.fl. Der Spiegel 2004, 1, 9496; fodboldspillere Der Spiegel 2003, 30, 92-95. Om sportsstjernerne se endvidere Whannel (2001).

18. http://www.sportsjones.com/sj/243-2.shtml. 19. FWS” FWS@listbot.com emne: Kournikova and SI (Sports Illustrated).

20. WOSPORT WEEKLY 13.9.2000, Women's Sports Foundations nyhedsbrev. 


\section{LITTERATUR}

- Andrews, David L. \& Jackson, Steven J. (2001): "Introduction: Sport Celebrities, Public Culture, and Private Experience", in Andrews, David L. \& Jackson, Steven J. (Eds.): Sport stars. The cultural politics of sporting celebrity. Routledge, London.

- Bach, Alice R. (2002): Kvinder på banen. Sport, køn og medier. Rosinante, Kbh.

- Bernstein, Alina. (2002). "Is it time for a victory lap? Changes in the media coverage of women in sport", in International review for the sociology of sport, vol. 37, 2002(3-4), 415-428.

- Bernstein, Alina and Blain, Neil (2003): "Sport and the Media: the Emergence of a Major Research Field", in Bernstein, Alina and Blain, Neil (Eds.): Sport, Media, Culture: Global and Local Dimensions. Frank Cass, London.

. Connell, Robert W. (2002): Gender. Polity, Cambridge.

- Creedon, Pamela J. (Ed.) (1994): Women, Media and Sport: Challenging Gender Values. Sage Publications, London/Thousand Oaks.

- Denfeld, Rene (1997): Kill the Body, the Head

Will Fall: Women, Violence and Aggression. Warner Books, New York

· Douglas, Delia D. (2002): "To be young, gifted, black and female: A meditation on the cultural politics at play in representations of Venus and Serena Williams", in Sport Sociology Online 5, 2002/2 (http://physed.otago.ac.nz/sosol/v5i2/ v5i2_3.html)

- Duncan, Margaret; Messner, Michael and Williams, Linda (1991): Coverage of Women's Sport in Four Daily Newspapers. AAF Publications, Los Angeles.

- Flax, Jane (1987): "Postmodernism and Gender Relations in Feminist Theory", in signs 12, 1987, 621-643.

- Goldman, Robert and Papson, Stephen (1998): Nike Culture: the Sign of the Swoosh. Sage, London. - Harris, John and Clayton, Ben (2002). "Femininity, Masculinity, Physicality and the English Tabloid Press. The case of Anna Kournikova“, in International review for the sociology of sport, vol. 37, 2002(3-4), 397-413.

- Hartmann-Tews, Ilse and Pfister, Gertrud (Eds.) (2003): Sport and Women. Social Issues in International Perspective. Routledge, London/New York. - Hartmann-Tews, Ilse and Rulofs, Bettina (1998): "Entwicklung und Perspektiven der Frauen- und Geschlechterforschung im Sport", in Kölner Forum, 1998/1, 3-13.

- Heywood, Leslie (1998): Bodymakers: a Cultural Anatomy of Women's Body Building. Rutgers University Press, New Brunswick, New Jersey.
• Heywood, Leslie (2004): "Athletic vs. Pornographic Eroticism: How Muscle Magazines Compromise Female Athletes and Delegitimize the Sport of Bodybuilding in the Public Eye". (Internet article) http://www.mesomorphosis.com/articles/heywood/eroticism.htm

- Heywood, Leslie and Dworkin, Shari L. (2003): Built to Win: the Female Athlete as Cultural Icon. University of Minnesota Press, Minneapolis, Minnesota.

- Kane, Mary Jo and Greendorfer, Susan (1994): "The Media's Role", in Creedon, Pamela J. (Ed.): Women, Media and Sport: Challenging Gender Values. Sage, Thousand Oaks, 28-45.

- Klein, Marie-Luise and Pfister, Gertrud (1985): Goldmädel, Rennmiezen und Turnküken. Die Fran in der Sportberichterstattung der BILD-Zeitung. Bartels \& Wernitz, Berlin.

- Lorber, Judith (1994): Paradoxes of Gender. Yale University Press, New Haven.

- Lorber, Judith (2000): "Using Gender to Undo Gender: a Feminist Degendering Movement", in Feminist Theory, 1, 2000/1, 79-96.

- Pfister, Gertrud (1994): "Beauty Awards versus Gold Medals-Olympic Women`s Sports Mirrored by the German Press (1928-1980)", in Takacs, Ferenc (Ed.): The 100 Year History of Olympism in the Mirror of Sciences. Hungarian Sport University, Budapest, 25-36.

- Pfister, Gertrud (1999): Sport im Lebenszusammenhang von Frauen. Ausgewählte Themen. Hofmann, Schorndorf.

- Pope, Harrison G.; Phillips, Katharine and Olivardia, Roberto (2001): Der Adonis-Komplex: Schönheitswahn und Körperkult bei Männern. dtv, München.

- Rakow, Lana (1986): "Rethinking Gender Research in Communication", in Journal of Communication, 36, 1986, 18-34.

- Tauziat, Nathalie (2000): Les Dessous du Tennis Féminine. Plon, Paris.

\section{SUMMARY}

In recent years, a new level of commodification and sexualisation of female athletes can be observed. Athletes, women as well as men, enact and market themselves with an up to now unseen energy and intensity. Today not only the performance in the sport grounds counts, but also the appearance and the image of the athletes who play a new role in 
mass media and in public. Using a constructivist approach to gender as a starting point, this paper demonstrates these new trends using Anna Kournikova as an example. Anna Kournikova's popularity is based mainly on her appearance and her image; her sporting performances play a secondary role. This article describes the changes in the presentation and the enactment of the athletes in sport and media sport. It analyses the motives of the athletes to signal sexuality and present themselves as sex objects. And it identifies changes in mass media that led to a focus on buman interest stories and sexualised images in media. The article focuses on the interrelations between the developments of sport, the public representation of sport in mass media and the role of female athletes in sport and in the sport coverage. Among other things, the globalisation of sport, the increasing performance level, the costs of top level sport, the competition between mass media and the interest of the audiences in the erotic attractiveness of sport stars are discussed as reasons for the "Kournikova syndrome".

Gertrud Pfister, dr.habil, professor i idrætssociologi ved Institut for Idræt, Københavns Universitet 